\title{
ETHICAL REVIEW OF RESEARCH INVOLVING HUMAN SUBJECTS IN NIGERIA: LEGAL AND POLICY ISSUES
}

\author{
Remigius N. Nwabueze*
}

\section{INTRODUCTION}

In 1999, the United States National Bioethics Advisory Commission (NBAC) commissioned an empirical study to analyze the impact of U.S. regulations on the conduct of United States biomedical research sponsored in Nigeria. 'The study, conducted by Patricia Marshall, was part of the NBAC's larger project on the ethical and policy issues involved in clinical trials in developing countries. On April 30, 2001, ${ }^{2}$ NBAC produced its recommendations in two volumes; volume one contained analyses and recommendations, ${ }^{3}$ and volume two contained the reports on commissioned studies. Marshall's case study of genetic epidemiology research in Nigeria highlighted the various problems confronting researchers and ethics review committees in Nigeria. Specifically, the study focused on the implications of cultural relativism on the implementation of United States rules of informed consent in Nigeria. ${ }^{4}$ Though Marshall was not concerned with broader issues, such as the general regulation of research involving human participants in Nigeria, the analysis provides a useful forum for beginning such an important discussion.

Some problematic ethical issues in the conduct of biomedical research have gained notoriety in the wake of globalization of biomedical research. These issues have attracted much attention in recent years, warranting copious

* Remigius N. Nwabueze, Assistant Professor of Law, Faculty of Law, University of Ottawa, Canada. I would like to thank Professor Trudo Lemmens, Faculty of Law, University of Toronto, Canada for his comments on the earlier draft of this article. I would also like to acknowledge the generous support of Genome Canada, through the Ontario Genomics Institute, in the research and writing of this article.

1. See Patricia A. Marshall, The Relevance of Culture for Informed Consent in U.S.Funded International Health Research in Ethical and Policy Issues in International Research, in II CliniCal TRIals IN DEveloping COUNTRIES, Commissioned PaPERS AND STAFF ANALYSIS (NBAC 2001).

2. Presidential Bioethics Commission Issues Report on Clinical Trials Research in Developing Countries, National Bioethics Advisory Commission (Apr. 30, 2001), available at http:www.bioethics.gov (last visited Nov. 11, 2003).

3. National Bioethics Advisory Commission, ETHICAL ISSUES IN INTERNATIONAL RESEARCH: CLINICAL TRIALS IN DEVELOPING COUNTRIES: REPORT AND RECOMMENDATIONS OF THE NATIONAL BIOETHICS ADVISORY COMMISSION (2001) [hereinafter NBAC].

4. See O.O. Ajayi., Taboos and Clinical Research in West Africa, 6 J. MED. ETHICs 61, 63 (1980) (discussing the impact of custom, tradition, and worldview on the conduct of biomedical research). See also C.B. Ijsselmuiden \& R.R. Faden, Sounding Board: Research and Informed Consent in Africa-Another Look, 326 NEW ENG. J. MED. 830, 831 (1992). 
recommendations by the NBAC ${ }^{5}$ and the Nuffield Council on Bioethics. ${ }^{6}$ The conduct of biomedical research and clinical trials in developing countries ${ }^{7}$ could be motivated by altruistic concerns to help developing countries confront particular health care problems, thereby reducing the inequality in global health research expenditures. ${ }^{8}$ However, this conduct (i.e. biomedical research) could also exploit and take advantage of the abundant research subjects, poverty and disease, low level of regulation, and comparatively cheaper cost of clinical trials in developing countries. ${ }^{9}$ For instance, a developed country's pharmaceutical corporation may undertake clinical trials in a developing country simply out of convenience and to quickly generate clinical data that would support drug registration application in the developed country. ${ }^{10}$

A myriad of factors contribute to recent public sensitivity to trials in developing countries. This includes the placebo-controlled trials that took

5. NBAC, supra note 3.

6. See Nuffield Council on Bioethics, The Ethics of Research Related to HealthCARE in DEVEloping Countries (2002).

7. The expressions "developing" and "developed" countries have contested meanings and are not used here in any technical sense. The term "developing" is used to describe nonindustrialized countries in South Africa that are still caught in the throes of poverty and economic underdevelopment. Similarly, "developed" is used to describe industrialized and wealthy countries in North Africa.

8. See Ad Hoc Committee on Health Research Relating to Future Intervention Options, Investing in Health Research and Development: Report of the Ad Hoc Committee on Health Research Relating to Future Intervention Options (World Health Organization) (1996). The World Health Organization estimated that $90 \%$ of health care research money in the world is applied to diseases representing less than $10 \%$ of the global burden of disease. See id. In other words, only $10 \%$ of the global health research budget is devoted to diseases afflicting about $90 \%$ of the world's population; these are mainly people in the developing countries. See id. See also Commission on Health Research for Development, Health Research: Essential Link to Equity in Development (Oxford University Press 1990); Global Forum for Health Research, The 10/90 Report on Health Research (Global Forum for Health Research 1999).

9. Rebecca A. Finkenbinder, New Recommendations on International Human Research: Can Minimum Standards Prevent the Exploitation of Vulnerable Human Subjects in Developing Countries, 21 PENN ST. INT'L L. REv 363, 364 (2003).

10. This was part of the motivation for the proposal sent in 2001 to the U.S. Food and Drug Administration by a Pennsylvania biotechnology company to conduct clinical trials of a drug for the treatment of infant's lung disease in Latin America. The trial used a placebo-arm (inert) considered unethical in the United States because of the availability of established surfactant drugs. Similar trials proposed in Europe would not use a placebo. See Mary Pat Flaherty \& Joe Stephens, Pa. Firm Asks FDA To Back Experiment Forbidden in U.S., WASH. POST, Feb. 23, 2001, at A3. The president of the Pennsylvania company estimated that the trial could shave eighteen months off of the development of the experimental drug. See id. The NBAC considers this proposed study to be unethical:

In studies of this kind-in which the disease is life threatening, an established effective treatment is available, patients in developed countries will be the primary beneficiaries of the results of the clinical trial, and it is not clear that the clinical trial is responsive to the health needs of the host country-a placebo control would not be permissible under the rules recommended in this report.

NBAC, supra note 3, at 25. 
place in various developing countries" that tested the efficacy of a short course zidovudine (AZT) in the reduction of perinatal transmission of HIV/AIDS. These trials raised the ethical issue of whether ethically unacceptable research in a developed country (for instance, the United States) could be ethically appropriate in a developing country; in other words, whether the standard of care in research is universal or dependent on local circumstances. ${ }^{12}$ Another factor that drew public attention to international clinical trials concerned the ethical propriety of Pfizer's 1996 clinical trial in Nigeria that tested the efficacy of trovan in the treatment of epidemic meningitis. ${ }^{13}$

The aforementioned context demands that developing countries rethink the availability and extent of protection accorded research participants in their territories. Accordingly, this paper explores the legal, policy and ethical frameworks for the regulation of biomedical research in Nigeria. Part I traces the history of biomedical research in Nigeria from the colonial period to contemporary times and observes that there is no formal regulation of biomedical research involving human participants in Nigeria. Part II examines some of the international biomedical research scandals and presents them as a context

11. The countries included in the trials were: Cote d'Ivoire (Ivory Coast), Burkina Faso, Ethiopia, Kenya, Malawi, South Africa, Tanzania, Uganda, and Zimbabwe.

12. Other than to illuminate public sentiment on research in developing countries, this paper is not concerned with the ethical controversy over the AZT trials in some developing countries. The trial was halted in 1998 when sufficient evidence in Thailand made its continuation unnecessary. See Sheryl Gay Stolberg, Placebo Use Is Suspended in Overseas AIDS Trials, N.Y. TIMES, Feb. 19, 1998, at A16. For more information about the AZT trials and ethical debates, see generally P. Fidler, "Geographical Morality" Revisited: Intemational Relations, International Law, and the Controversy Over Placebo-Controlled HIV Clinical Trials in Developing Countries, 42 HARV. INT'L L.J. 299 (2001); Leonard H. Glantz, et al., Research in Developing Countries: Taking 'Benefit' Seriously, Hastings Center Rep., at 38 (Nov.-Dec. 1998); Jonathan Todres, Can Research Subjects of Clinical Trials in Developing Countries Sue Physician-Investigators for Human Rights Violations?, 16 N.Y.L. SCH. J. HUM. RTS. 737 (2000); Ronald Bayer, The Debate Over Maternal-Fetal HIV Transmission Prevention Trials in Africa, Asia, and the Caribbean: Racist Exploitation or Exploitation of Racism? 88 AM. J. Pub. Health 567 (1998); David Orentlicher, Universality and its Limits: When Research Ethics Can Reflect Local Circumstances, 30 J.L. MED. \& ETHICS 403 (2002); Eldryd Parry, The Ethics of Clinical Research in Developing Countries, 34 J. RoYAL. C. PHYSICIANS LON. 328 (2000); Joanne Roman, U.S. Medical Research in the Developing World: Ignoring Nuremberg, 11 CORNELL J.L. \& PUB. POL'Y 441 (2002); Robert Levine, International Codes of Research Ethics: Current Controversies and the Future, 35 IND. L. REv. 557 (2002); Harold Varmus \& David Satcher, Ethical Complexities of Conducting Research in Developing Countries, 337 NEW ENG. J. MED. 1003 (Oct. 2, 1997); Peter Lurie \& Sidney M. Wolfe, Unethical Trials of Interventions to Reduce Perinatal Transmission of the Human Immunodeficiency Virus in Developing Countries, 337 NEW ENG. J. MED. 853 (Sept. 18, 1997); Marcia Angell, The Ethics of Clinical Research in the Third World, 337 NEw ENG. J. MED. 847 (Sept. 18, 1997); George Annas and Michael Grodin, Human Rights and Maternal-Fetal HIV Transmission Prevention Trials in Africa, 88 AM. J. PuB. HeALTH 560 (1998); Robert A. Crouch and John D. Arras, AZT Trials and Tribulations, Hastings Center Rep., at 26 (Nov.-Dec. 1998); Carol Levine, Placebos and HIV: Lessons Learned, Hastings Center Rep., at 43 (Nov.-Dec. 1998).

13. Joe Stephens, Doctors Say Drug Trial's Approval Was Backdated, WASH. POST, Jan. 16, 2001, at A1; Sonia Shah, Globalizing Clinical Research: Big Pharma Tries Out First World Drugs On Unsuspecting Third World Patients, THE NATION, July 1, 2002, at 23. 
for the controversial drug trials in Nigeria in 1996. Part III reviews Pfizer's controversial drug trial in Nigeria and highlights its problematic aspects. Part IV discusses the concept and nature of ethical review of biomedical research. Specifically, Part IV examines recent CIOMS guidelines, particularly the provisions regarding ethical review of research sponsored in a host country by a foreign country or organization. This part laments the lack of a functional and credible system of ethics review in Nigeria and that many Nigerian research institutions lack a firmly established, competent, independent, and functional ethics review board. Part V suggests that urgent steps should be taken in Nigeria to promulgate a formal guideline for_conducting research involving human subjects, and that international and regional institutions should help Nigeria in building capacity for ethical review. ${ }^{14}$ Here, it is also suggested that the few ethics committees in Nigeria, financially and administratively hampered in the discharge of their duties, should seriously consider the option of charging fees in a way that does not affect their independence.

This paper is not concerned with specific ethical problems that arise in the planning and conduct of biomedical research such as informed consent, selection of subjects, compensation, availability of research result in the host country, randomization, and the ethics of placebo-controlled studies. ${ }^{15}$ The focus on the general regulatory structure in Nigeria is not intended to underestimate the value of specific issues, which legitimately deserve future attention. Moreover, a formal and comprehensive research guideline, promulgated as suggested in this paper, would likely set out the bases for resolving the specific ethical issues in ways that respond to cultural and national circumstances. ${ }^{16}$

\section{History of Biomedical Research in Nigeria.}

As a political entity, Nigeria attained statehood on October 1, 1960. However, biomedical research started in the colonial era, long before Nigeria gained its political independence from Great Britain. In 1920, the Rockefeller Foundation initiated a colonial research enterprise in the west coast of Africa

14. For instance, the Swiss Commission for Research Partnership with Developing Countries (KFPE) has a guideline that purports to ensure that collaborative projects lead to capacity building in developing countries. See KFPE, Guidelines for Research in Partnership with Developing Countries, Principle 10 (1998), available at http://www.kfpe.ch/download/ guidelines_e.pdf (last visited Sept. 15, 2003).

15. These issues were considered in the report of the NBAC, supra note 3. See also NUFFIELD COUNCIL ON BIOETHICS, supra note 6. See generally Dawn Joyce Miller, Research and Accountability: The Need for Uniform Regulation of International Pharmaceutical Drug Testing, 13 PACE INT'L L. REV. 197 (2001).

16. For instance, it was suggested that the imposition of western bioethical values on nonwestern peoples and cultures amount to ethical imperialism. See M. Angell, Ethical Imperialism? Ethics in International Collaborative Clinical Research, 319 NEW ENG. J. MED. 1081 (Oct. 20, 1988). 
known as the "Rockefeller Foundation Yellow Fever Commission to the West Coast of Africa."17 In 1925, the Yellow Fever Commission, as it was generally called, built a Research Unit in Yaba, Lagos. ${ }^{18}$ Few details are known about any clinical trial or other activities by the Yellow Fever Commission, but, considering that ethics review was developed in the 1960 s, ${ }^{19}$ yellow fever research would probably raise only issues of informed consent.

In 1954, the British colonial government established the West African Council for Medical Research for its West African territories of Nigeria, Ghana, Gambia, and Sierra Leone. ${ }^{20}$ The main function of the Council was to arrange for the conduct of medical research in those West African territories and to provide medical research information concerning West Africa to the British government. ${ }^{21}$ Legislation establishing the Council was not specific on the type of medical research to be conducted or sponsored by the Council, nor did it contain any provision relating to the ethics review of research protocols conducted under the auspices of the Council.

In 1952, the Nigerian colonial government established the University College Hospital, Ibadan (UCH). ${ }^{22}$ UCH was established as a teaching hospital of the University of Ibadan (then University College, Ibadan). Part of the mandate of the UCH was to carry out clinical research or other medical experimentation, ${ }^{23}$ though no research guideline was specifically mentioned. ${ }^{24}$ Following the UCH research mandate, subsequent teaching hospitals established in Nigeria were given the same clinical research jurisdiction. ${ }^{25}$

In 1972, the then Nigerian Military government established the Medical Research Council of Nigeria (MRC) ${ }^{26}$ The federal agency was responsible for the conduct of medical research in Nigeria. However, in 1977, the National Science and Technology Development Agency ${ }^{27}$ (NSTDA) was statutorily

17. See The National Institute of Medical Research, Yaba Lagos, Nigeria, available at http:www.nimr-ng.org./NIMR-nav.htm (last visited Nov. 11, 2003).

18. Id.

19. The first ethical review committee was established in the United Kingdom in 1966. See P. Ferguson, Do Researchers Feel an LREC Hinders Research?, 165 BULL. OF MED. ETHICS 17, 19 (2001). In the United States the policy that made it mandatory for a review of federal-funded research by an Institutional Review Board began in 1966. See id.; Roman, supra note 12 , at 455 .

20. West African Council for Medical Research Ordinance, Laws of the Federation of Nigeria and Lagos, Cap. 215 (1958).

21. Id. \& 3 .

22. University College Hospital Act, Laws of the Federation of Nigeria and Lagos, Cap $205, \S 3$ (1958).

23. Id. $\$ 12(1)$.

24. At that period the main international medical research guideline was the Nuremberg Code, which I shall discuss later.

25. Such as the University of Nigerian Teaching Hospital; University of Lagos Teaching Hospital; University of Benin Teaching Hospital, and Obafemi Awolowo University Teaching Hospital.

26. Decree No. 1, Medical Research Council of Nigeria (1972).

27. Decree No. 5, National Science and Technology Development Agency Decree (1977). 
established in Nigeria to advise the federal government on matters relating to scientific research and development. The NSTDA Decree repealed the Medical Research Council of Nigeria Decree $1972 .{ }^{28}$ Pursuant to the NSTDA Decree, the Research Institute's Order of $1977^{29}$ established the National Institute of Medical Research in Yaba Lagos (NIMR). The assets and rights of the MRC were transferred to the NIMR. ${ }^{30}$ The NIMR is authorized to conduct medical research related to health problems in Nigeria and to cooperate with Nigerian medical schools and universities to provide the necessary facilities for training medical researchers in Nigeria. Though the NIMR is a major Nigerian institute concerned with human medicine and research in Nigeria, it has not promulgated any formal guideline for the conduct of research involving human subjects.

\section{International Context of Biomedical Research: Research Scandals.}

Recent research scandals in Nigeria have raised ethical anxieties that are better understood in a historical perspective. This involves the clinical trial of trovan for the treatment of epidemic meningitis. Also important are questions of the ethical appropriateness of placebo-controlled studies in some African countries used to determine the effect of a short-course zidovudine in reducing prenatal transmission of HIV. ${ }^{31}$ Institutional or ethics review of biomedical research ${ }^{32}$ has some interesting international historical background.

In the nineteenth century, gonorrhea and syphilis studies were undertaken by medical scientists who were characterized by Vikenty Veressayev as "bizarre disciples of science," and "zealots of science," in Germany, France, Russia, Ireland, and the United States of America. ${ }^{33}$ The gonorrhea study involved the inoculation of gonorrhea-free (healthy) patients without their consents with pure cultures of gonococcus to prove that it was the agent responsible for gonorrhea. ${ }^{34}$ Similar inoculations were undertaken with respect to syphilis to demonstrate that it was contagious in its secondary stage. ${ }^{35}$ The syphilis study was so outrageous that even after Ricord, the greatest opponent of the hypothesis that secondary syphilis was contagious, had accepted his error, unethical and unconsented inoculations with the disease were still

28. Id. $\& 11$, Schedule 3.

29. Research Institutes (Establishment, etc.) Order 1977, Annual Volume of the Laws of the Federal Republic of Nigeria (1977).

30. Id. § 8(c).

31. For African countries involved in the trial and the literature on the debate, see supra notes 11-12.

32. Known in Canada as a Research Ethics Board (REB) and in the United States as the Institutional Review Board (IRB).

33. VIKENTY VERESSAYEV, THE MEMOIRS OF A PHYSICIAN 332-66 (Alfred A. Knopf ed., \& Simeon Linden trans., 1916).

34. Id.

35. Id. 
carried out by some investigators, despite the abundant scientific proof contrary to their hypothesis, thus rendering more victims to science. ${ }^{36}$

\section{A. The Tuskegee Syphilis Study.}

Between 1930 and 1973, the U.S. Department of Public Health Services (USPHS) conducted research on the natural progression of syphilis in Tuskegee, Macon County, Alabama. ${ }^{37}$ The research subjects in the Tuskegee study were mainly poor African- Americans, many of whom suffered from syphilis but were denied treatment as part of the study design despite the availability of penicillin in the $1950 \mathrm{~s}$ as an effective treatment for the treatment of the disease. ${ }^{38}$ Even before penicillin became standard care for syphilis, arsenotherapy was available during the study as an effective treatment for the disease. Nonetheless, the subjects were denied that intervention because of the study's predication on nontreatment. ${ }^{39}$ Moreover, participants in the Tuskegee study were prevented from obtaining private treatment for the disease even though medical and health services were available. ${ }^{40}$ When some of the Tuskegee study subjects died, the USPHS induced family members to give consent for anatomical examination for the last stage of the study.

The subjects of the Tuskegee study were told that the objective of the study was to treat them, so instead of obtaining their informed consent, the USPHS deliberately deceived them. ${ }^{41}$ Also, the study was not submitted to nor approved of by an ethics committee. ${ }^{42}$ However, ethics review procedures did not come into existence until the $1960 \mathrm{~s}^{43}$ For the USPHS, it is arguable that since ethics review procedures are not retrospective, the USPHS was justified to believe that the Tuskegee study, which began in the 1930s, was excluded from review. Though this argument offers some vindication, the USPHS remains morally responsible for the ethically problematic research.

In the early 1970 s, the Tuskegee study was made public, necessitating the empanelling of an ad hoc advisory committee. The committee presented a report to the Assistant Secretary for Health in 1973 with scathing findings that the Tuskegee study was not undertaken with the informed consent of

36. Id.

37. JAMES H. JONES, BAD BLOOD: THE TUSKEGEE SYPHILIS EXPERIMENT (1993).

38. The 40-Year Death Watch, MED. WORLD NEwS, Aug. 18, 1972, at 15-17; Doleres Katz, Why 430 Blacks with Syphilis Went Uncured for 40 Years, DETROIT FREE PRESS, Nov. 5 , 1972.

39. Allan M. Brandt, Racism and Research: The Case of the Tuskegee Syphilis Study, Hastings Center Rep. 21, 26-27 (1978), available at http://www.sciencemag.org/cgi/content/ full/284/5416.919 (last visited Aug. 25, 2003).

40. See id. at 25.

41. See id. See also Amy L. Fairchild \& Ronald Bayer, Uses and Abuses of Tuskegee, 284 SCIENCE 919 (May 7, 1999), available at http://www.sciencemag.org/cgi/content/full/284/ 5416/919 (last visited Sept. 23, 2003).

42. JONES, supra note 37 , at 1 .

43. See Ferguson, supra note 19. See also Roman, supra note 19. 
research subjects and that the subjects were unjustifiably denied penicillin when it became available in the $1950 \mathrm{~s}^{44}$ Civil litigation brought by surviving research subjects and the estates of diseased ones followed, but ended in monetary settlements. More troubling for the Tuskegee study was that despite the 1940s enunciation of the Nuremberg Code on the ethics of medical research and the wide public uproar ignited by the publicizing of the unethical research at the Jewish Chronic Disease Hospital in the $1960 \mathrm{~s},{ }^{45}$ the Tuskegee study continued without alteration. The unjustifiable continuation of the Tuskegee study may be with some racist undertones. ${ }^{46}$ Brandt strongly argued that the historical context of the study captured the racist prejudice against African Americans, and then-prevailing medical attitudes toward blacks, disease, and sex. Furthermore, it underpinned the dismissive and lackadaisical attitude of the medical community and U.S. government until horrors of the study were brought to the peoples' conscience by the U.S. press. ${ }^{47}$ A contemporary consequence of the Tuskegee study is the current distrust of medical experimentation and medical researchers that African-Americans hold. ${ }^{48}$

\section{B. The Nuremberg Medical Case}

It was the trial of Karl Brandt and others (now called the Medical Case) between 1946 and 1947 by the Nuremberg Military Tribunal that shook the confidence of the international community in the propriety of leaving research subject protection and welfare to the sole judgment and conscience of an investigator. $^{49}$ The Karl Brandt trial revealed horrendous experiments conducted by some Nazi scientists and physicians on prisoners in concentration camps without their consent or any form of ethics or institutional review. ${ }^{50}$

44. Department of Health, Education, and Welfare, Final Report of the TUSKEGEE SYPHILIS STUDY AD HOC ADVISORY PANEL (1973).

45. JAY KaTZ, EXPERIMENTATION WITH HuMAN BEINGS: THE AUTHORITY OF THE INVESTIGATOR, SUBJECT, PROFESSIONS, AND STATE IN THE HUMAN EXPERIMENTATION PROCESS 10-11 (1972).

46. Some authors have argued that there is a connection between racism and certain experimentation with human subjects. See Annette Dula, Yes, There Are African-American Perspectives on Bioethics, in BIOETHICS: AN INTRODUCTION TO THE HISTORY, METHODS, AND PrACTICE 252-54 (Nancy S. Jecker et al. eds., 1997); Herbert Aptheker, Racism and Human Experimentation, 53 POL. AFFAIRS 27-60 (1974); Brandt, supra note 39.

47. Brandt, supra note 39.

48. THE Human RADIATION EXPERIMENTS, FINAL REPORT OF THE PRESIDENT'S ADVISORY COMMITTEE (1996). See also Fairchild \& Bayer, supra note 41.

49. M. GRODIN, Historical Origins of the Nuremberg Code, in THE NAZI DOCTORS AND THE NUREMBERG CODE: HUMAN RIGHTS IN HUMAN EXPERIMENTATION 121-44 (G.J. Annas \& M. Grodin eds., 1992); Matthew Lippman, The Nazi Doctors Trial and the International Prohibition on Medical Involvement in Torture, 15 LOY. L.A. INT'L COMP. L.J. 410 (1993).

50. Such unethical experiments included the following: deliberate infection with typhus, malaria, and epidemic jaundice, yellow fever, smallpox, paratyphoid, cholera, and diphtheria to test the efficacy of experimental vaccines and drugs; high-altitude experiments in which nonconsenting subjects were locked in low pressure chambers that mimicked the atmospheric 
Though the defendants at the Nuremberg Military Tribunal claimed that their actions were justifiable under the existing domestic law and were not condemned by then prevailing international law, the Tribunal presented ten basic principles of ethical, moral, and legal complexion that provided the measure of the defendants' actions. ${ }^{51}$ These principles crystallized into what is known as the Nuremberg Code, ${ }^{52}$ and they set minimum standards for the ethical conduct of biomedical research. Normatively, the Nuremberg Code is at least part of customary international law ${ }^{53}$ and binds member states of the United Nations. ${ }^{54}$ However, its existence has not prevented subsequent research scandals. ${ }^{55}$

conditions and pressures prevailing at high altitude up to 68,000 feet; freezing experiments in which victims were denuded and exposed for long hours to temperatures below freezing point or placed inside a tank of ice water; deliberate infliction of battle-like wounds and aggravated infection thereof to test the efficacy of sulfanilamide and other drugs; deliberate poisoning of the food of victims to determine the effects of certain poisons and bullets on human beings; sexual sterilization experiments using surgery, high-dose $\mathrm{x}$-rays, and pharmacological techniques; and the deliberate killing of some Jewish prisoners to provide skulls and skeletons for cranial and racial research at the Reich University of Strasbourg. See United States v. Karl Brandt, reprinted in KATZ, supra note 45, at 292-94.

51. Excerpt of the judgement of the Nuremberg Military Tribunal is reproduced in CLINICAL INVESTIGATION IN MEDICINE: LEGAL, ETHICAL, AND MORAL ASPECTS 116-19 (Irving Ladimer \& Roger W. Newman eds., 1963).

52. For the early attempts at the international level to codify the principles enunciated by the Nuremberg Military Tribunal, see ROBERT K. WOETZEL, THE NUREMBERG TRIALS IN INTERNATIONAL LAW 232-44 (1962).

53. Pascal Arnold \& Dominique Sprumont, The 'Nuremberg Code': Rules of Public International Law, in ETHICS CODES IN MEDICINE: FOUNDATIONS AND ACHIEVEMENTS OF CODIFICATION SINCE 194790 (Ulrich Tröhler \& Stella Reiter-Theil eds., 1998).

Due to the Nuremberg Code's continuing and uniformed applications (usus) by a majority of countries, as well as the general recognition of its binding nature (opinio juris), these basic principles have become rules of customary international law. In fact, they are applied in the common interest of all nations and are so deeply rooted in the international legal consciousness that they constitute peremptory public international law (ius cogens). This means that they cannot be modified by any State or professional organization, either by statute or ethical guidelines.

Id. See also Todres, supra note 12 , at $750-52$.

54. CHRISTINE V. D. WYNGAERT \& GUY STESSENS, INTERNATIONAL CRIMINAL LAW: A COLLECTION OF INTERNATIONAL AND EUROPEAN INSTRUMENTS 50 (1996).

55. For instance, in 1963, twenty-two chronically ill and debilitated patients at the Jewish Chronic Disease Hospital (JCDH) in Brooklyn were given injections of live cancer cells to study their immunologic status, or their rejection responses. The study was a non-therapeutic clinical research project and was funded by the United States Public Health Service and the American Cancer Society. See letter from Chester M. Southam, M.D. to Emmanuel Mandel, M.D. on July 5, 1963, reprinted in JAY KATZ, EXPERIMENTATION WITH HUMAN BEINGS: THE AUTHORITY OF THE INVESTIGATOR, SUBJECT, PROFESSIONS, AND STATE IN THE HuMAN EXPERIMENTATION PROCESS 10-11 (1972). The patients' consent was not obtained and the study was not submitted for institutional review. See id. The litigation that followed exposure of this unethical research, brought by one of the directors of $\mathrm{JCDH}$, gives useful insights into the mood of the public concerning human subject experimentation. Id. Despite investigation by the State Department of Education and Kings County District into the JCDH scandal, a director of the JCDH brought an action in court seeking access to medical records of the hospital to investigate 
The Western world witnessed other historic medical research scandals. For instance, the cold war motivated unethical radiation experiments conducted or sponsored by U.S. governmental agencies, ${ }^{56}$ the controversial experimental drug trials on U.S. soldiers during the $1991 \mathrm{Gulf}$ War, ${ }^{57}$ and research on deceased persons and their parts in Canada, ${ }^{58}$ the United States, ${ }^{59}$ the U.K., ${ }^{60}$

facts concerning the alleged unethical and improper experiments on some of the hospital's patients. See id. In Hyman v. Jewish Chronic Disease Hosp., 206 N.E.2d 338 (1965), the defendants argued that the hospital records were confidential and that the plaintiff was not personally liable for the wrongdoing and unethical research conducted by the hospital. The court held that as a director, the plaintiff was entitled to know the facts upon which the potential liability of the hospital rested. It further held that the plaintiff was entitled to inspect records that reveal improper and unethical research by the hospital and any confidentiality would be protected by an appropriate order of the court as to concealment of the names of individual patients. In addition, the Attorney General of New York, pursuant to the applicable Education Law, brought a petition in the Board of Regents Grievance Committee (BRGC) for the revocation of the licenses of the principal investigators (Dr. Southam and Dr. Mandel) in the cancer study. The BRGC found the investigators guilty of the allegations in the petition and recommended their censure and reprimand. While accepting the findings of the BRGC, the Board of Regents of the University of the State of New York modified the sentences by suspending the licenses of the investigators for a year but stayed execution of the suspension.

56. See Trudo Lemmens, In the Name of National Security: Lessons from the Final Report on the Human Radiation Experiments, 6 EUR. J. HEALTH L. 7-23 (1996); George J. Annas, Some Choice: Law Medicine, and the Market 157-60 (New York: Oxford University Press) (1998); E. Welsome, The Plutonium Experiment, AlBUQUERQUE TRIBUNE, Nov. 15-17, 1993; THE HUMAN RADIATION EXPERIMENTS, FINAL REPORT OF THE PRESIDENT'S ADVISORY COMMITTEE (1996); In re Cincinnati Radiation Litigation, 874 F. Supp 796 (S.D. Ohio 1995), Beckwith, J. observed:

The allegations in this case indicate that the government of the United States, aided by officials of the City of Cincinnati, treated at least eighty-seven of its citizens as though they were laboratory animals. If the Constitution has not clearly established a right under which these plaintiffs may attempt to prove their case, then a gaping hole in that document has been exposed. The subject of experimentation who has not volunteered is merely an object.

ld.

57. See George J. Annas, Changing the Consent Rules for Desert Storm, 326 NEw ENG. J. MED. 770 (Mar. 12, 1992). Though use of the experimental drugs (pyridostigmine bromide $30 \mathrm{mg}$ tablets and pentavalent botulinum toxoid vaccine) without prior consent of soldiers was allowed by the U.S. Food and Drug Administration (FDA), and subsequently by the court, the ethics of that incident remain controversial. See id. See also Annas, supra note 56, at 132-39; E.J. Schuchardt, Walking a Thin Line: Distinguishing Between Research and Medical Practice During Operation Desert Storm, 26 COLUM. J. L. \& SoC. PROB. 77-115 (1992); G.J. Annas \& M.A. Grodin, Treating the Troops: Commentary, 21 Hastings Center Rep. 24 (1991); Informed Consent for Human Drugs and Biologics; Determination That Informed Consent Is Not Feasible, Fed.Reg. 1990; 55: 52813-52817;21 C.F.R. § 50.23(d); Doe v. Sullivan, 756 F. Supp 12 (D.C. Cir. 1991); Doe v. Sullivan, 938 F.2d 1370 (D.C. Cir. 1991).

58. Charlie Gillis, Doctor Left Autopsies Unfinished in Halifax: Children's Organs Found in Warehouse, NAT'L POST, Oct. 3, 2000, at A8.

59. Paul Wildie, Husband Sues After Brain Tissue Taken From Dead Wife, NAT'LPoST, Jan. 29, 2000, at A13; Peter Gorner, Parents Suing Over Patenting of Genetic Test: They Say Researchers They Assisted are Trying to Profit From a Test for a Rare Disease, CHI. TRIB., Nov. 19, 2000, at Al.

60. Stephen White, The Law Relating to Dealing with Dead Bodies, 4MED. L. INT'L 145 (2000). 
and Australia, ${ }^{61}$ without a family member's consent. ${ }^{62}$ However, contemporary research scandals in the West mainly concern conflict of interest issues. ${ }^{63}$ Interestingly, a recent medical research scandal in Nigeria exhibits patterns of the historic genre. This may excuse any effort to sensitize developing countries to the ethically problematic aspects of medical research by drawing their attention to the unhappy historical moments of experimentation with human subjects. ${ }^{64}$

\section{Trovan Clinical Trial in Nigeria by Pfizer.}

During the first quarter of 1996, there was an epidemic outbreak of meningitis in Kano, a northern Nigerian city. Doctors Without Borders (a medical non-governmental organization) rushed to the area to provide treatment with a cheap and internationally recommended antibiotic, chloramphenicol. Within weeks of the epidemic, Pfizer also learned about it from an internet site and quickly mobilized its research team to fly into the Nigerian city of Kano and conduct a clinical trial of its new drug, trovafloxacin (hereafter, trovan). It seemed that objections from Dr. Juan Walterspiel, a Pfizer medical scientist, regarding the ethics of the trial could not deter Pfizer, which later dismissed Dr. Walterspiel from its employment. ${ }^{65}$

The trial, which started on or about March 22, 1996, was to determine the efficacy of trovan in the treatment of meningococcal meningitis and to compare it to ceftriaxone, the gold standard for treating the disease. The trial

61. Michael Perry, Body-Parts Supermarket Causes Uproar in Australia: No consent for Research, NAT'L POST, Mar. 20, 2001, at A13.

62. See generally Remigius N. Nwabueze, Biotechnology and the New Property Regime in Human Bodies and Body Parts, 24 LoY. L.A. INT'L \& COMP. L. REV. 19 (2002).

63. There is a growing body of literature on conflict of interest in biomedical research. See David Blumenthal, Biotech in Northeast Ohio Conference: Conflict of Interest in Biomedical Research, 12 HEALTH MATRIX 377 (2002); J.A. Goldner, Dealing with Conflicts of Interest in Biomedical Research: IRB Oversight as the Next Best Solution to the Abolitionist Approach, 28 J.L. MED. \& ETHICs 379 (2000); K.C. Glass \& T. Lemmens, Conflict of Interest and Commerciliazation of Biomedical Research: What Is the Role of Research Ethics Review?, in THE COMMERCIALIZATION OF GENETIC RESEARCH: ETHICAL, LEGAL AND POLICY ISSUES 79 (T. Caulfied \& B. Williams-Jones eds., 1999); CoNFLICTS OF INTEREST IN CLINICAL PRACTICE AND RESEARCH (R.G. Spece et al. eds., Oxford University Press 1996); M. Little, Research, Ethics and Conflicts of Interest, 25 J. MED. ETHICs 259 (1999); R.A. Phillips \& J. Hoey, Constraints of Interest: Lessons at the Hospital for Sick Children, 159 C.M.A.J. 955 (1998); A Curious Stopping Rule from Hoechst Marion Roussel, 350 LANCET 155 (July 19, 1997); Good Manners for the Pharmaceutical Industry, 349 LANCET 1635 (June 7, 1997); E.J. Emmanuel \& D. Steiner, Institutional Conflict of Interest, 332 N. Eng. J. Med. 262 (1995); K.C. Glass \& T. Lemmens, Research Involving Humans, in CANADIAN HEALTH LAW AND POLICY 459, 46675 (J. Downie et al. eds., 2002); Grimes v. Kennedy Krieger Institute, 782 A.2d 807 (2001).

64. Henry K. Beecher, Medical Ethics and Medical History: Experimentation in Man, in CLINICAL INVESTIGATION IN MEDICINE: LEGAL, ETHICAL AND MORAL ASPECTS, supra note 51, at 2-39.

65. Tamar Lewin, Families Sue Pfizer on Test of Antibiotic, Aug. 30, 2001, at http://www.mercola.com/2001/sep/8/pfizer.htm (last visited Nov. 11, 2003). 
was conducted in the Kano Infectious Disease Hospital, part of the hospital complex of Aminu Kano University Teaching Hospital. Two hundred Nigerian children were enrolled in the study; one hundred of them were assigned to the trovan arm, while the other one hundred were used as active controls and were given ceftriaxone, though it was alleged that some of the children in the control group were not given the proper dosage of ceftriaxone. At the end of the trial, five children on the trovan arm died and six children on the control arm died. Many others were alleged to have suffered brain damage, paralysis, or became deaf. Pfizer is yet to make any follow-up visit to the Nigerian research participants.

Pfizer was accused of not obtaining informed consent from the parents of the children enrolled in the study. The parents of the research participants could not speak English, and they believed that their children were receiving effective treatment rather than being enrolled in clinical research. ${ }^{66}$ Pfizer denied the claims made against it, alleging that nurses at the hospital explained the study in lay terms to the parents and obtained their verbal consent. Pfizer further alleged that those parents were informed that alternative treatment, offered by Doctors Without Borders (operating in the same hospital), was available, and that in terms of percentage, the death toll from the study was lower than that of the disease. Pfizer claimed that the study was primarily a humanitarian effort that saved about 189 lives, and made drugs and equipment available to the hospital. However, a commentator questioned Pfizer's humanitarian claims and asked: "But why ... did [Pfizer] not fly in substantial supplies of the rather more expensive drug it was using as a comparison to Trovan so that every sick child could have a better chance of life?"67

More relevant for this article, however, is the allegation that ethical approval for the trovan study was not given by Nigerian authorities, contrary to Pfizer's contention. ${ }^{68}$ In 1997, when Pfizer submitted its application to the U.S. Food and Drug Administration for the use of trovan in the treatment of a meningitis epidemic, it included a document purporting to have approval for the Nigerian study given by the Kano Infectious Disease Hospital's ethics committee. However, in a recent telephone interview by the Washington Post with some of the Nigerian doctors who participated in the study (and those alleged to have been members of the ethics committee) ${ }^{69}$ it was revealed that the ethical approval letter was written one year after the study had taken place and was backdated. The telephone interview further disclosed that the Kano

66. Id.

67. Sarah Boseley, Ailing Ethics: A Clinical Trial Raises Disturbing Questions About Drug Companies' Activities in Africa, THE GuARDIAN, Jan. 20, 2001, at 20, available at http://www.guardian.co.uk/comment/story/0,3604,425450,00.html (last visited Sept. 5, 2003).

68. See Sam Eferaro, NAFDAC Okayed Pfizer's Trovan Trials, VANGUARD DaILY (Lagos) Jan. 8, 2001. The Nigerian National Agency for Food and Drug Administration and Control (NAFDAC), however, did approve the importation of trovan into Nigeria. Id.

69. Joe Stephens, Doctors Say Trial's Approval Was Backdated, WASH. POST, Jan. 16, 2001, at A1. 
Hospital did not have an ethics committee at the time of the clinical trial. ${ }^{70}$ What is often not clear in some of the materials on the Nigerian trovan trial is whether Pfizer also obtained ethical review and approval of the Nigerian study in United States, as required by international guidelines and U.S. domestic legislation. If the Washington Post's position on the lack of ethical approval for the trovan study was accepted, then it is arguable that the omission contributed to the death of some of the Nigerian children in the study, though it is not clear that if there had been a proper and effective ethics committee, it would have stopped the study or made it achieve positive results.

Trovan reached the U.S. market in 1998, and made about $\$ 160$ million in the first year, but its use was not approved for children. In 1999, following complaints of liver damage, the FDA further restricted its use. ${ }^{71}$ The trovan study in Nigeria has been the subject of administrative inquiry in Nigeria, ${ }^{72}$ and has been litigated in Nigerian and the U.S. courts. ${ }^{73}$ It has also helped to draw attention to the unacceptable consequences of some biomedical studies sponsored by external agencies and corporations in developing countries. Probably more important, it has helped to highlight the importance of and need for ethics review of research in many developing countries.

\section{The Concept and Nature of Ethical Review.}

As part of the international and domestic response to some of the above scandals, many current research guidelines embody an important procedural ethics requirement. ${ }^{74}$ This means that a research protocol must receive the prior approval of an ethics committee before its execution. ${ }^{75}$ Guideline 2 of the Council for International Organization of Medical Sciences (CIOMS) provides that every research proposal involving human beings must be "submitted for review of their scientific merit and ethical acceptability to one or more scientific review and ethics review committees." World Medical Association research guideline (the Declaration of Helsinki) stipulates that experimental protocol involving human subjects "should be

70. Id.

71. See Lewin, supra note 65.

72. Pfizer Drug Trial in Nigeria Being Investigated, 357 LANCET 9250 (Jan. 13, 2001).

73. See Lewin, supra note 65.

74. WORLD Health ORganization, Operational Guidelines for ETHICS COMMITTEES THAT REVIEW BIOMEDICAL RESEARCH (2000) [hereinafter WHO]; see also NBAC, supra note 3 , at 5 . The NBAC observed that "ethically sound research must comply with an important procedural requirement-prior ethical review by a body that is competent to assess compliance with these substantive ethical principles." Id.

75. See generally Bowen HoSford, Bioethics COMmTtees: The Health CARE PROVIDER's GUIDE 8-16 (1986).

76. Council For InTERnational ORganization of Medical Sciences, InTERNATIONAL ETHICAL GUIDELINES FOR BIOMEDICAL RESEARCH INVOLVING HUMAN SUBJECTS CIOMS, Guideline 2 (2002), available at $\mathrm{http}: / / \mathrm{www}$. cioms.ch/frame_guidelines_nov_2002.htm (last visited Sept. 5, 2003) [hereinafter CIOMS]. 
submitted for consideration, comment, guidance, and where appropriate, approval to a specially appointed ethics review committee."77 The guideline by International Conference on Harmonization (ICH-GCP) ${ }^{78}$ and many domestic and national guidelines require similar provisions. Research on identifiable human tissues or data is included within the rubric of "research involving human beings," or "human experimentation."

Generally, the normative character of some of the guidelines makes them legally and judicially unenforceable,$^{80}$ though other means of enforcement, such as discipline by a professional group or denial of funding by a grant agency, may be available. Institutional or ethical review of clinical research, or any research involving human subjects, has become an acceptable standard for determining the ethics of human experimentation. ${ }^{81}$ The framework of institutional review is intended to protect the rights, safety, and welfare of research subjects, ${ }^{82}$ and to promote public confidence and trust in biomedical investigation and integrity of the process. ${ }^{83}$ Institutional review has also become the cornerstone of biomedical research funding and its emergence was suggested to have been partly responsible for the progressive increase in biomedical research budgets and funding in the United States. ${ }^{84}$ Though the mere existence of an ethics review committee neither guarantees the complete absence of unethical research ${ }^{85}$ nor necessarily facilitates societal confidence in the integrity and responsibility of scientific researchers, it does promise to

77. World Medical Association, Ethical Principles for Medical Research Involving Human Subjects, Oct. 2000, World Medical Assembly, art. 13 [hereinafter Declaration of Helsinki].

78. INTERNATIONAL CONFERENCE ON HARMONIZATION OF TECHNICAL REQUIREMENTS FOR REgISTRATION OF PHARMACEUTICALS FOR HUMAN USE-GOOD CliniCAL PRACTICE: CONSOLIDATED GUIDELINE, ICH, May 1996. See also, WHO, Guidelines for Good Clinical Practice (GCP) for Trials on Pharmaceutical Products, WHO Technical Report Series, No. 850 (1995); Proposal for a European Parliament and Council Directive on the Approximation of Provisions Laid Down by Law, Regulation or Administrative Action Relating to the Implementation of Good Clinical Practice in the Conduct of Clinical Trials on Medicinal Products for Human Use, COM (97) 306 final.

79. See LADIMER \& NEWMAN, supra note 51, at 18. See also CIOMS, supra note 76, Guideline 1, commentary; Declaration of Helsinki, supra note 77, art. 1.

80. See The Common Rule, 45 C.F.R. $\$ 46 ;$ the U.S. Food and Drug Administration, 21 C.F.R. $\$ 50,21$ C.F.R. $\$ 56,21$ C.F.R. $\$ 312 ;$ U.S. Agency for International Development, 22 C.F.R. $\$ 225$ (all explaining that in the United States, the guideline on human subjects protection and the ethical review of research involving human participants is statutory and judicially enforceable).

81. See NUFFid COUNCIL ON BIOETHICS, supra note 6, at 101.

82. See WHO, supra note 74, at 1.

83. Robert A. Pearlman, Introduction to the Practice of Bioethics, in BIOETHICS: AN INTRODUCTION TO THE HISTORY, METHOD AND PRACTICE, supra note 46, at 260-61.

84. NATHAN HERSHEY \& ROBERT D. MLIER, HUMAN EXPERIMENTATION AND THE LAW 1-2 (Aspen Systems Corporation 1976).

85. NUFFIELD COUNCIL ON BIOETHICS, supra note 6, at 103 (documenting examples of unethical biomedical research conducted in the United States despite the existing Nuremberg Code). 
be a veritable framework for curbing the excesses of protocols that pay scant attention to other overriding societal values. ${ }^{86}$ As Pope Pius XII once said that "science is not the highest value to which all other orders of values ... should be subordinated." 87 Thus, the existence of ethics review reaffirms society's conviction that social or moral considerations should be infused into scientific enterprise. $^{88}$

Apart from professional or industrial self-regulation, there are at least four regulatory models of ethics review. ${ }^{89}$ Thus, a valid statute or piece of legislation could make ethics review a legal requirement for the conducting of research involving human beings. ${ }^{90}$ Penal sanctions could accompany noncompliance. ${ }^{91}$ Less specifically, formal legislation may compulsorily require biomedical research institutions to devise their own ethics review systems. Furthermore, government research agencies may develop guidelines that make ethics review a prerequisite for funding. ${ }^{92}$ Lastly, ethics review may be incorporated by a cross-reference national legislation. ${ }^{93}$

Whatever the mode of regulation, an ethics review committee should possess certain core characteristics. ${ }^{94}$ It should be independent of the investigators conducting the research, as well as competent and multi-disciplinary in nature so as to provide a complete review of the scientific and ethical aspects a protocol. ${ }^{95}$ It should not have, or must at least declare, any interest that conflicts with an objective assessment of a protocol, ${ }^{96}$ and should be able to monitor a study after approval. ${ }^{97}$ An ethics review committee should have the power to reject a protocol that it considers to be ethically problematic, and to

86. A.M. Capron, Human Experimentation, in MEDICALETHICs 156 (Robert M. Veatch ed., 2nd. ed. 1997).

87. Pope Pius XII, The Moral Limits of Medical Research and Treatment 1952, Rome, Italy: Address Presented at First International Congress on Histopathology of Nervous System, at http://www.ewtn.com/library/PAPALDOC/P12PSYCH.htm (last visited Mar. 19 2003).

88. Id.

89. Marie Hirtle, Trudo Lemmens, \& Dominique Sprumont, A Comparative Analysis of Research Ethics Review Mechanisms and the ICH Good Clinical Practice Guideline, 7 EUR. J. HEALTH L. 267 (2000).

90. See supra note 80. See also Simon Verdun-Jones \& David N. Weisstub, The Regulation of Biomedical Research Experimentation in Canada: Developing an Effective Apparatus for the Implementation of Ethical Principles in a Scientific Milieu, 28 OTTAWA L. REV. 297, 340 (1996-97).

91. Hirtle, Lemmens, \& Sprumont, supra note 89, at 268.

92. Id.

93. Id.

94. Verdun-Jones \& Weisstub, supra note 90, at 330-39; CIOMS, supra note 76, Guideline 2; Declaration of Helsinki, supra note 77, art. 13.

95. WHO, supra note 74 , at $2-3$.

96. Id. at 4.

97. JUDITH WILSON ROSS, HANDBOOK FOR HOSPITAL ETHICS COMMITTEES 31-70 (1986); HOSFORD, supra note 75. 
accept a scientifically and ethically sound protocol with or without modifications. ${ }^{98}$

\section{A. Ethical Review in Nigeria}

Nigeria does not have any formal regulatory system of ethics review, or research guideline produced by the country's medical research institutions or governmental agencies that fund medical research. This regulatory deficiency was probably responsible for the trovan tragedy in Nigeria. No state or federal statutory enactment in Nigeria directly regulates the conduct of research involving human subjects, though a variety of statutes may indirectly impinge on human subject experimentation in Nigeria. It is arguable that the regulatory void in many African countries, ${ }^{99}$ including Nigeria, is a deliberate health policy by these countries, geared towards attracting desperately needed biomedical research sponsored by developed foreign countries, multinational corporations, and international organizations. ${ }^{100}$ Often access to health care services and expensive interventions needed to combat the scourge of diseases, like HIV/AIDS, can only be obtained in many developing countries through participation in clinical trials. Thus, attracting these trials by means of favorable regulatory environment ensures access to highly needed health care.

The unsatisfactory regulatory situation in many African countries could also be the result of institutional incapacity in bioethics or the feeling that available international ethical guidelines make domestic regulation otiose. ${ }^{101}$ With struggling economies, absence of $\mathrm{R} \& \mathrm{D}$ capacity, and faced with the HIV/AIDS pandemic, in addition to other public health emergencies like malaria and tuberculosis, African countries are tempted to take advantage of foreign-sponsored research enterprises, even when they entail insignificant respect for the autonomy, rights, and welfare of research subjects. Thus, poverty and disease, in combination with other factors, make it difficult for some developing countries to adopt a formal regulatory approach that may

98. CIOMS, supra note 76, Guideline 2. See also, Benjamin M. Meier, International Protection of Persons Undergoing Medical Experimentation: Protecting the Right of Informed Consent, 20 BERKELEY J. INT'L L. 513, 542 (2002) (observing that the ethical committee recommended by the Helsinki Declaration did not have any power to reject protocols that infringed informed consent rules).

99. The few African countries that have research ethics guidelines include Uganda and South Africa. See generally Sana Loue \& David Okello, Research Bioethics in the Ugandan Context II: Procedural and Substantive Reform, 28 J.L. MED. \& ETHICs 165 (2000); Guidelines on Ethics for Medical Research, at http://www.mrc.ac.za/ethics/ethics.htm (last visited Sept. 22, 2003); Guidelines for Good Practice in the Conduct of Clinical Trials in Human Participants in South Africa, at http://196.36.153.56/doh/docs/policy/trials/trials_contents.htm (last visited Sept. 22, 2003).

100. See Miller, supra note 15, at 212; Meier, supra note 98, at 532-34.

101. Zulfiqar A. Bhutta, Ethics in International Health Research: A Perspective from the Developing World, 80 BULL. WORLD HEALTH ORG. 114, 115 (2000), available at http://who .int/docstore/bulletin/pdf/2002/bul-2-5-2002/80(2)114-120.pdf (last visited Sept. 5, 2003). 
inhibit potentially beneficial biomedical experimentation. But it is doubtful whether under-regulation or zero regulation in a developing country legitimizes a clinical trial sponsored therein in breach of international ethical guidelines, the Nuremberg Code, and the domestic law of the sponsors. ${ }^{102}$

Evidence of a regulatory structure in Nigeria arises only by implication of its membership in certain international bodies, either directly or through professional organizations in Nigeria. Because the Nigerian Medical Association (NMA) ${ }^{103}$ is a member of the World Medical Association, ${ }^{104}$ the Helsinki Declaration, which provides for ethics review of research involving human beings, applies in Nigeria to research conducted by members of the Nigerian Medical Association. ${ }^{105}$ The obvious gap is that there is no other form of an ethical review requirement for human subject research conducted by nonphysicians in Nigeria, physicians who are not members of the Nigerian Medical Association, and private entities in Nigeria. ${ }^{106}$ Though the Nuremberg Code has force in Nigeria as a peremptory norm of public international law, ${ }^{107}$ it does not impose a requirement for ethical review. The unsatisfactory regulatory situation in Nigeria may be a reflection of its comparatively low biomedical research activities. After a visit to some teaching hospitals in Nigeria in 2001 and 2002, my personal impression was that some of them only have a faint idea of what ethical review means, and only a few of them probably have an established ethical review committee, functioning more or less on an ad hoc basis. For instance, there are ethical review committees in the teaching hospitals of the University of Lagos, and the University of Ibadan. ${ }^{108}$ These are Nigerian universities in big cities that attract significant international collaboration in biomedical research. For instance, the collaboration in the 1990s between some Nigerian investigators and US researches on the genetic and environmental determinants of hypertension, breast cancer, and diabetes mellitus in Nigeria. ${ }^{109}$

102. See Todress, supra note 12; Lewin, supra note 65 (regarding possible legal liability in this kind of scenario).

103. Nigerian Medical Association, at http://www.nigeriannma.org (last visited Sept. 5, 2003).

104. Id.

105. P.I. Okolo, Medical Ethics in Nigeria, in MEDICAL PRACTICE \& THE LAW IN NIGERIA 8-19 (Benjamin C. Umerah ed., 1989).

106. See A.A. Christakis \& J. Panner, Existing International Ethical Guidelines for Human Subjects Research: Some Open Questions, 19 LAw, MEDICINE, \& HEALTH CARE 214, 217 (1991) (addressing limitations of the Helsinki Declaration, which indirectly applies in Nigeria). "International ethical guidelines are not, however, despite any invocation to such effect, designed to be a code capable of regulating conduct in specific situations. Without further elaboration and implementation on a local level, the broad aspirational notions expressed remain no more than that-a valuable but incomplete system." Id.

107. Tröhler \& Reiter-Theil, supra note 53.

108. Marshall, supra note 1 , at 4.

109. Id. 
It is tempting to suggest that even the few Nigerian institutions that provide ethical review committees do so in response to collaborative studies with the United States whose legislation obliges such a review in a host country. ${ }^{110}$ The corollary is that many potential research subjects in Nigeria are likely to be denied of the protections afforded by the existence of a regular, functional, and competent ethics committee. ${ }^{111}$

\section{B. Ethical Review of Externally Sponsored Research in Nigeria.}

As observed above the ethical review of biomedical research is generally not developed in Nigeria and is likely to be available only with respect to externally sponsored research. Guideline 3, CIOMS (2002) provides for the ethical review of externally sponsored research as follows:

An external sponsoring organization and individual investigators should submit the research protocol for ethical and scientific review in the country of the sponsoring organization, and the ethical standards applied should be no less stringent than they would be for research carried out in that country. The health authorities of the host country, as well as a national or local ethical review committee, should ensure that the proposed research is responsive to the health needs and priorities of the host country and meets the requisite ethical standards. ${ }^{112}$

To qualify as an externally sponsored research, the research (or part of a multipart trial) should be undertaken in a host country "but sponsored, financed, and sometimes wholly or partly carried out by an external international or national organization or pharmaceutical company with the collaboration or agreement of the appropriate authorities, institutions and personnel of the host country." 113

Guideline 3 aims to ensure that biomedical research undertaken in a resource-poor country, such as many African and developing countries, is given proper ethical consideration that recognizes the rights, dignity, and

110. See, e.g., the Common Rule, 45 C.F.R. $\$ 46.101$. Similarly, the National Bioethics Advisory Committee observed that in " 29 percent of studies reported by U.S. researchers, the host country ethics review committee was established because of U.S. regulations." NBAC, supra note 3, at 82. See also N. Kass \& A. Hyder, Attitudes and Experiences of U.S. and Developing Country Investigators Regarding U.S. Human Subjects Regulations, in National Bioethics Advisory Commission, II ETHICAL AND POLICY ISSUES IN INTERNATIONAL RESEARCH: CLINICAL TRIALS IN DEVELOPING COUNTRIES (2001).

111. See WHO, supra note 74.

112. CIOMS, supra note 76 , Guideline 3.

113. Id. 
welfare of the research subjects. ${ }^{114}$ This provision becomes more crucial in the context of low regulatory visibility in many African host countries, and the temptation for researchers from developed and wealthy sponsoring countries to think that the abundance of impoverished research subjects in a region of near regulatory void is a warrant for ethical impropriety. ${ }^{115}$ Globalization not only of goods and services but also of clinical trials has brought the aforementioned temptation within the realm of reality. ${ }^{116}$ Because of a number of factors present in developing countries-for instance low income, widespread unemployment, illiteracy, poverty and disease-citizens of developing countries are much more vulnerable and available to be research subjects. ${ }^{117}$ These factors, in addition to a favorable regulatory climate in many developing countries, comparative reluctance by citizens of developed countries to enroll as research subjects, bureaucratic control of research in many wealthy nations, and low cost of conducting clinical trials in developing countries, make it more advantageous for some biomedical researchers and industries in the North to conduct their clinical trials in developing countries. ${ }^{118}$

Regrettably, the globalization of biomedical research has left in its wake evidence of the unsavory consequences of the economic inequality between the north and south. ${ }^{119}$ For instance, Chang described how the human-subject experimentation relating to $H$. Pylori bacterium conducted by the United States National Cancer Institute in a rural province of China in 1988 led to an increase of about forty percent in the disease infection. ${ }^{120}$ Without any form of legally enforceable post-trial obligation on visiting researchers, research injuries of this kind will be rampant in developing countries. The willingness of drug agencies in some developed countries to accept data generated from a clinical trial in a developing country would only intensify the current rush for human research subjects abroad. ${ }^{21}$ Though globalization of clinical trials

114. Robert J. Levine, International Codes of Research Ethics: Current Controversies and the Future, 35 IND. L. REV. 557, 563 (2002).

115. Ileana Dominguez-Urban, Harmonization in the Regulation of Pharmaceutical Research and Human Rights: The Need to Think Globally, 30 CORNELL INT'L L. J. 245, 270-71 (1997).

116. See Flaherty \& Stephens, supra note 10, at A3. "Drugmakers in the United States and other wealthy nations are increasingly testing new medicines in developing countries where costs are low, patients plentiful and government oversight lax." Id.

117. Shah, supra note 13, at 1-6; Miller, supra note 15, at 219-20.

118. Id. See also NBAC, supra note 3, at 1 .

119. Esther Chang, Fitting a Square Peg into a Round Hole?: Imposing Informed Consent and Post-Trial Obligations on United States Sponsored Clinical Trials in Developing Countries, 11 S. CAL. INTERDISC. L.J. 339 (2002) (discussing the ethical and legal problems of conducting clinical trials in developing countries and the reaction of the US National Bioethics Advisory Commission in 2000).

120. Id.

121. US Food \& Drug Administration, Guidance for Industry: Acceptance of Foreign Clinical Studies (2001), available at http://www.fda.gov/cber/gdlns/clinical031301.htm (last visited Sept. 22, 2003). See also Lisa R. Pitler, Ethics of AIDS Clinical Trials in Developing Countries: A Review, 57 FOOD \& DRUG L. J. 133, 152 (2002). 
is theoretically unproblematic, it is necessary that rapid internationalization of ethical guidelines and standards should accompany this globalization and hinder the potential opportunities for abuse of clinical trials in poor, developing countries. Thus, to reduce the risk of ethical misconduct during biomedical research in a host country, Guideline 3, above, stipulates a two-fold process of ethical review.

First, the relevant ethical review board in the sponsoring country would scrutinize the proposed research both for its scientific and ethical validity. Even at this stage, the sponsoring country's review board is required to take into consideration the customs and traditions of the host country that may influence the ethics of the proposed research. Since members of the review board are geographically distanced and likely to be unfamiliar with the cultures of a foreign country, adequate cultural sensitivity, and an understanding of how the culture affects the review process may be difficult to achieve. In recognition of this problem, the commentary on Guideline 2 recommends that a sponsor country's ethical review committee should include someone conversant with the customs and traditions of the host country. ${ }^{122}$ If we accept Benatar and Singer's call for a proactive approach to international research ethics, ${ }^{123}$ then it becomes clear that a sponsor's ethics committee would have socioeconomic and political considerations that may be external to strict ethical review. ${ }^{124}$ These authors contend that because of gross inequality in global health, foreign investigators should demonstrate sufficient knowledge of the social, economic, and political circumstances of the host country in which their research takes place. Host countries may ultimately benefit from this demonstration because the foreign investigators "might influence political leaders in their countries to promote more equitable relations with the host country in which the research was conducted."125 This represents an ideal to be pursued. However, whether a sponsor's ethics committee should reject ethical protocol based on an investigator's insufficient knowledge of the socioeconomic and political history of the host country is not clear.

The second stage of the two-fold review process of externally sponsored research is the submission of the protocol to the relevant ethics board in the host country, which must ensure that the research is scientifically and ethically

122. CIOMS, supra note 76, commentary on Guideline 2.

123. Solomon R. Benatar \& Peter A. Singer, A New Look at International Research Ethics, 321 BMJ 824 (2000).

124. These considerations have already been identified by Benater and Singer as knowledge of:

(a) the sociology of pharmaceutical research; (b) the political relation between the sponsoring and host countries-for example, how the host country fits into the sponsoring country's policy, what economic aid is provided, the nature of any debt relations, and the extent of arms trading between the two countries; and (c) Id. at 826.

the human rights achievements of the sponsoring and host countries.

125. Id. 
sound with regard to its overall circumstances and that it meets the host country's needs and priorities. ${ }^{126}$ It is important for the host country's ethics committee to review not only the ethical merit of the protocol, but also its relevance to the host country's priorities, which could be medical or socioeconomic. ${ }^{127}$ For instance, in a resource-poor host country with a small pool of doctors, which are desperately needed for more pressing medical emergencies, their diversion to externally sponsored research on a less prevalent disease, such as cancer, may be in dissonance with the priorities of the host country. Dickens noted the ability of sponsored studies in host countries to distort the priorities of the host and reflect those of the sponsors. ${ }^{128} \mathrm{He}$ opined that the "diversion of assets from host countries' priorities to those of developed study-sponsoring countries, even when what is accomplished in a host country is of value, is a form of imperialism."129

Though a host country's ethical review is potentially capable of obviating this bioethical imperialism, considerable problems arise for host countries without any form of a regular and functional ethical review board. In a bid to attract potentially beneficial biomedical research, a poor host country may quickly raise an ethics committee with little or no idea of its mandate. Such a review committee will simply rubber-stamp the protocol at the expense of the rights, welfare, and dignity of research subjects. ${ }^{130}$ What should be done in these circumstances? Should a sponsoring country abandon the research due to the incapacity of ethical review in the host country? Should it conduct such research even when it compromises international ethical guidelines or domestic legislation of the sponsor? In other words, is under-regulation or zero regulation an excuse for conducting ethically problematic research in a host country? ${ }^{131}$

126. The National Bioethics Advisory Commission recommended that "[c]linical trials conducted in developing countries should be limited to those studies that are responsive to the health needs of the host country." NBAC, supra note 3, at 8.

127. See B.M. Dickens, Research Ethics and HIV/AIDS, 16 MED. LAW 187, 195 (1997). See generally Anthony Costello \& Alimuddin Zumla, Moving to Research Partnerships in Developing Countries, 321 BMJ 827 (2000), available at http://www.bmj.bmjjournals.com (last visited Oct. 4, 2003).

128. Id.

129. Id.

130. The NUFFIELD COUNCIL ON BIOETHICS observed that:

In some instances, researchers may submit research for approval in developing countries, only to have it 'approved' within a few days, with no amendments of changes proposed. Under these circumstances concerns have been expressed that officials in developing countries do not recognize the need for effective ethical review and consider it to be simply a formality.

NUFFIELD COUNCIL ON BIOETHICS, supra note 6, at 104.

131. It has been suggested that ethical and legal lapses by U.S. investigators who conduct clinical trials abroad which result in injury to participants are actionable in the United States. See Todres, supra note 12, at 750. Similarly, some of the victims of the Nigerian trovan trial brought a case in the U.S. that is still pending. See Lewin, supra note 65. 
Though different answers to these questions are possible, a strict adherence to the provisions of the CIOMS guideline would mean that a sham ethical review is equivalent to no review at all. This means that, absent a competent and functional ethics committee in the host country, executing a research protocol may amount to an infraction of international ethical guidelines. Moreover, the loose regulatory situation in the host country does not exempt the sponsor from any domestic legislation (in the sponsoring country) that compulsorily requires ethical review in a host country. Even without such a requirement, it is morally unconscionable for a foreign investigator or agency to conduct in a host country research that would be ethically problematic and impermissible in the sponsor's country.

Furthermore, the provisions of CIOMS as to the constitution ${ }^{132}$ and composition ${ }^{133}$ of an ethics review board does not differentiate between a host and sponsoring country, or a developing and developed country. Thus, a sponsoring country should, despite the willingness of a host country to forgo strict compliance with ethical review requirement, insist on a proper review conducted by a competent ethics board. The sponsor should exhibit a stand on ethical review that countervails the desperation of a host country. Dickens suggests that a sponsor could assist in developing the ethical review capacity for the host country. ${ }^{134}$ Another author suggests that funding ethical review in the host country should be reflected in the protocol and be part of the ethical review in the sponsoring country. ${ }^{135}$ These suggestions are legitimate and acceptable provided the sponsor does not, in the guise of providing institutional capacity, supplant the ethical review in the host country. Thus, help should relate to such matters as training, education, and supply of equipment. Where, however, the sponsor is a private, multinational corporation with considerable commercial interest in the research, it may find the unsatisfactory regulatory situation in the host country very convenient, and probably unwilling to insist on real ethical review.

\section{Conflict of Ethical Expectations.}

Even with the availability of competent and efficient ethical review in both of sponsor and host countries, cultural relativism potentially ensures contradictory review by both committees. For instance, a seroprevalance study in Tanzania entailed sampling the blood of an infant upon birth as well as its mother's blood. ${ }^{136}$ A U.S. Institutional Review Board approved the study on

132. See CIOMS supra note 76, Guideline 2.

133. Id.

134. See Dickens, supra note 127 , at 828.

135. See Robert Mittendorff II, Primum Non Nocere: Implications for the Globalization of Biomedical Research Trials, 25.2 FLETCHER F. WORLD AFF. 239, 247 (2001).

136. See Michele Barry, Ethical Considerations of Human Investigation in Developing Countries: The AIDS Dilemma, 319 NEW ENG. J. MED. 1083 (1988). 
the condition that research participants would be informed of the test results. ${ }^{137}$ However, Tanzanian authorities demanded that the research subjects should neither know of the blood draws nor the test results. This attitude reflected local sensitivity to the trauma consequential to disclosure of HIV status and lack of effective intervention in Tanzania. Because of this conflict, the study was abandoned. ${ }^{138}$ Conflict in ethical expectations is a significant problem that demands urgent attention and critical analysis. A host country's ethical committee may find proposed research ethical and in accordance with its cultural norms and traditional lifestyle. However, an ethics committee of the sponsor with a different cultural background may find the same protocol unethical. In that case, the protocol would not pass the requirement of concurrent review and approval; thus, potentially beneficial research would be abandoned due to cultural differences. ${ }^{139}$ However, there may be ways to negotiate this problem. ${ }^{140}$ First, a protocol that satisfies the ethical requirement of the host country may easily find favor with the ethical committee in the sponsor-country, even when it does not strictly comply with the sponsor's ethical guidelines. ${ }^{141}$ Second, the host country's ethical review committee might be given a presumptive claim to ethical guidance. ${ }^{142}$ Third, the host and sponsor country's ethical review committees may cooperate and agree that each reviews specific and different aspects of the protocol in a non-contradictory manner. This type of cooperation is encouraged by CIOMS. ${ }^{143}$

137. Id.

138. Id.

139. NUFFIELD COUNCIL ON BIOETHICS noted that:

Where there are irreconcilable differences between research ethics committees, a committee may choose not to approve the research. If a committee from a sponsoring country does not approve the research, the sponsor cannot fund it. If a research ethics committee from a developing country does not approve the research, then the research cannot be conducted within that country.

NUFFIELD COUNCIL ON BIOETHICS, supra note 6, at 108.

140. See NUFFIELD COUNCIL ON BIOETHICS, supra note 6, at 107-08 (suggesting a negotiation that mediates the differences between the two committees). See also Christakis \& Panner, supra note 106, at 219.

141. Dickens, supra note 127 , at 196 . This may easily be the case where the sponsor country has cultural affinity with the host country. For instance, a U.S. Institutional Review Board may be willing to accept the review of a Canadian Ethics Review Board due to cultural and legal similarities between the two countries.

142. See Christakis \& Panner, supra note 106, at 219.

The host country for the research, or, more specifically, the representatives of research subjects, should have a presumptive claim to ethical guidance. In the event of a conflict, the host country's ethical standards, if they are more restrictive, should always prevail. In other words, if there are tow interpretations of what would be ethical-one favoring the research and the other barring the research-if the interpretation barring the research is favored by the host community, the research must be viewed as unethical.

Id.

143. See CIOMS, supra note 76 , Guideline 3 , commentary. 
In the Nigerian context, however, empirical data gathered by Marshall shows that the aforementioned bioethical negotiation and mediation may be difficult to achieve. She reported that some Nigerian investigators perceived U.S. institutions to be inflexible and not amenable to culturally sensitive modifications suggested by the Nigerian investigators. ${ }^{144}$

\section{Policy and Legal Options for Nigeria.}

\section{A. Promulgation of a Research Ethics Guideline.}

As this review shows, Nigeria does not have formal and systematic guidelines for the conduct of research involving human participants, except to the extent that the Helsinki Declaration or the guidelines of a sponsoring country are indirectly applicable. This regulatory deficiency is deplorable considering the significant number of teaching hospitals in the country, some of which are already engaged in important international biomedical research collaboration. ${ }^{145}$ Under-regulation increases the potential risk of exploitation in Nigeria by international corporations seeking clinical trials in countries with zero or minimal regulation. ${ }^{146}$ Moreover, Nigeria's regulatory situation disqualifies it from taking advantage of certain provisions of the U.S. Common Rule. For instance, there is a provision in the Common Rule that permits reliance on a host country's ethics guidelines. ${ }^{147}$ The criteria for making deter

144. See Marshall, supra note 1 , at C-25.

Nigerian investigators discussed administrative issues regarding the process of obtaining approval from ethical review committees. Several investigators commented on the difficulties of responding to the requirements of funding agencies in the United States and at local Nigerian institutions. They said it was particularly frustrating to try to respond to what they perceived as inconsistent requirements for ethical review. A physician in Lagos reported difficulties at many levels: dealing with the informed consent document itself, having to "fight with Washington" to change the consent form, and then going through the process of Id. making the form useful and appropriate for his patients in Nigeria.

145. See Marshall, supra note 1 , at C-11.

146. I have already argued that some developing countries deliberately adopt a policy of zero or minimal regulation in order to attract needed biomedical research. In that context, "exploitation" may not be an appropriate word to use for a corporation or foreign researcher that takes advantage of the policy.

147. The Common Rule, 45 C.F.R. $\$ 46.101(\mathrm{~h})$ states:

When research covered by this policy takes place in foreign countries, procedures normally followed in foreign countries... may differ from those set forth in this policy. [An example is a foreign institution which complies with guidelines consistent with the World Medical Assembly Declaration (Declaration of Helsinki amended 1989) issued either by sovereign states or by an organization whose function for the protection of human research subjects is internationally recognized.] In these circumstances, if a department or agency head determines that the procedures prescribed by the institution afford protections that are at least equivalent to those provided in this policy, the department or agency head 
minations of equivalence and the other complex issues surrounding it have not been systematically addressed by the relevant authorities in the United States. ${ }^{148}$ It is clear, however, that even assuming determinations of equivalence to be easy, Nigeria does not stand to gain from the above provision without any formal research ethics guidelines in Nigeria.

Accordingly, it is strongly recommended that urgent steps be taken in Nigeria to regulate biomedical research by the promulgation of research ethics guidelines. The guidelines could be statutorily enacted by each of the thirtysix States in Nigeria and/or the Federal Government of Nigeria. ${ }^{149}$ Relevant U.S. legislation could be helpful as a guide. Alternatively, the Nigerian Federal Ministry of Health, the Nigerian Medical Association, the National Institute of Medical Research, Lagos, and the Nigerian Institute of Pharmaceutical Research, Abuja could alone, or in combination, produce a formal and nonstatutory guideline similar to the Canadian Tri-Council Policy Statement. ${ }^{150}$ There are numerous examples of domestic and international guidelines to draw from. ${ }^{151}$ Nigeria will particularly benefit from the examples of fellow African countries, such as the guidelines in Uganda ${ }^{152}$ and South Africa. ${ }^{153}$

The AIDS pandemic in Uganda attracted considerable HIV/AIDS related research sponsored by foreign entities, and provided the catalyst for a profound national reflection on the ethics of biomedical research. This led to the 1997 promulgation of formal ethics guidelines for the conduct of research involving human participants in Uganda. The new Ugandan guideline took three years to materialize. The guideline is not a legally binding instrument and a summary account of its legislative history and provisions was given by Loue and

may approve the substitution of the foreign procedures in lieu of the procedural requirements provided in this policy.

Id.

148. See BeRnARD M. DiCKENS, The ChALLENGE OF EQUivalent (2001).

149. This may eventually turn on the legislative competence of the federal and state governments with respect to biomedical research involving human participants.

150. See generally Tri-Council Policy Statement: Ethical Conduct for Research Involving Humans, MEDICAL RESEARCH COUNCIL OF CANADA, NATURAL SCIENCES AND ENGINEERING RESEARCH COUNCIL OF CANADA, SOCIAL SCIENCES AND HUMANITIES RESEARCH COUNCIL OF CANADA (1998), available at http:/www.nserc.ca/programs/ethics/english/ethics-e.pdf (last visited Oct. 10, 2003).

151. See Dickens, supra note 148 , at 15 . (noting the multiplicity of such domestic and international guidelines).

152. GUIDELINES FOR THE CONDUCT OF HEALTH RESEARCH INVOLVING HUMAN SUBJECTS IN UGANDA (Nat'l Consensus Conference on Bioethics and Health Research in Uganda, 1997) [hereinafter THE UGANDAN GUIDELINE].

153. See GUIDELINES ON ETHICS FOR MEDICAL RESEARCH (1993), available at http://www.mrc.ac.za/ethics/ethics.htm (last visited Oct. 4, 2003). See also GUIDELINES FOR GOOD PRACTICE IN THE CONDUCT OF CliniCAL TRIaLS IN HUMAN PARTICIPANTS IN SOUTH AFRICA (2000), available at http://196.36.153.56/doh/docs/policy/trials/trials_01.html (last visited Oct. 4, 2003). 
Okello. ${ }^{154}$ The Ugandan guideline was preceded by a National Consensus Conference (NCC) with a diverse and all-encompassing representative membership. ${ }^{155}$ No doubt, the desirable constitution of the NCC facilitated acceptance of the guidelines it formulated. The provisions of the Ugandan guideline reflect an adroit contextualization of current international and domestic ethics guidelines in some developed countries. Specifically, the Ugandan guidelines reflect the need for an ethics guideline to be responsive to the peculiarities of a country, its history, culture, political, economic, social, and health conditions. ${ }^{156}$

The Ugandan guideline underscores the primacy of ethical review in the research enterprise by establishing a three-tier ethical review process, ${ }^{157}$ including the power to terminate or suspend any protocol conducted in contravention of original approval. ${ }^{158}$ Inculcating these lessons from Uganda would require that Nigeria begin to mobilize public debate on the desirability and means of realizing a formal ethical guideline regulating the conduct of research involving human subjects. The Nigerian media should play a leading role in that regard. ${ }^{159}$ Nigeria does not need to await an epidemic explosion of the scourge of HIV/AIDS before abandoning its flippant attitude towards biomedical research regulation. If any catalyst was needed, then the trovan trial in which several Nigerian children died was enough. ${ }^{160}$ It is regrettable that the Nigerian press quickly withdrew its searchlight on the trovan episode soon

154. Sana Loue and David Okello, Research Bioethics in the Ugandan Context II: Procedural and Substantive Reform, 28 J. L. MED. \& ETHICS 165 (2000). Loue and Okello also observed that the new Ugandan guideline lacked "a viable enforcement mechanism to ensure compliance with the Guidelines." Id. at 171.

155. For instance:

Voting representatives included individuals from various governmental organizations such as the Ministry of Health, the Ministry of Defense, the Attorney General's Office, the Uganda National Council of Science and Technology (UNCST), the National Drug Authority, and the National Cancer Institute; Makerere University; various medical associations, such as the Protestant Medical Association; nursing and pharmacists' professional organizations; various churches, legal service agencies, human rights organizations, and media personnel. The NCC had been widely advertised to encourage attendance and participation of non-affiliated persons. These include, for instance, university Id. at 165 .

students, participants in ongoing research, and freelance media personnel.

156. Because of the oppression of many Ugandans during the regimes of the country's tyrannical and despotic leaders, the Ugandan guideline broke ground with tradition and custom by requiring individual and voluntary informed consent rather than consent from a local leader, husband, or head of the family.

157. "The Guidelines establish multiple levels of review, beginning at the institutional level with institutional review committees (IRCs) and extending to the AIDS Commission for HIV-related research and to the NCST for all research, including that which is HIV-related." Loue \& Okello, supra note 154, at 165.

158. Id. at 166.

159. The Nigerian Medical Association should also play an active role in promoting public awareness of the ethics of biomedical research and the need for formal regulation.

160. See Shah, supra note 13 , at 4 . 
after it became known to the public, leading to a loss of regulatory momentum gained at the time of publication of the scandal.

\section{B. Building and Strengthening Capacity in Ethical Review.}

The review of research protocol by a competent and independent ethics review committee is a fundamental safeguard for research participants and promotes public confidence in the ethics of biomedical research. ${ }^{161}$ Despite the importance of ethical review, the procedure is lacking in some developing countries and poorly executed in others. Recall that the trovan scandal in Nigeria centered on the alleged lack of ethics approval before the commencement of the trial. ${ }^{162}$ As stated earlier, some Nigerian research institutions do not have an ethics review committee. Where evidence of ethics review capacity is present, it is probably due to collaboration with international researchers and research institutions, such as the United States.

For the few Nigerian institutions with any semblance of an ethical review process, ethics review is debilitated by a host of factors including administrative cost and lack of expertise in bioethics. According to an empirical study of some investigators in Nigeria, a researcher personally bore the administrative cost related to a protocol evaluation of an ethics review committee, despite the researcher's limited resources. ${ }^{163}$ It is, therefore, suggested that the proposed Nigerian biomedical research guideline should contain detailed provisions on the constitution, membership, function, and funding of an ethics review committee. Without sufficient funding and training programs for ethics committees, the ethics of biomedical research will not improve. ${ }^{164}$ The Nuffield Council on Bioethics estimated that the operating costs of a research ethics committee in the UK was about $£ 36,000$ and up to U.S. $\$ 500,000$ per annum in the United States. ${ }^{165}$ Though the cost of operating a research ethics committee in Nigeria is likely to be lower, it still represents a significant amount that may unduly burden the parent institution of an ethics committee. Thus, the federal government of Nigeria, through the Federal Ministry of Health, should financially support the ethics committees established in federal universities and research institutions, and the State Ministry of Health should provide similar support for a State university ethics committee.

161. WHO, supra note 74 , at $v$.

162. See Stephens, supra note 13 , at A1.

163. Marshall, supra note 1 , at C-25.

164. See Peter A. Singer \& Solomon R. Benatar, Beyond Helsinki: A Vision for Global Health Ethics, 322 BMJ 747-48 (2001), available at http://www.bmj.bmjjournals.com (last visited Oct. 4, 2003).

165. The NUFFIELD COUNCIL ON BIOETHICS, supra note 6, at 106. 
Moreover, Nigeria, and indeed many developing countries, will require international help in building and strengthening ethics review committees. ${ }^{166}$ Singer and Benatar have suggested the creation of a global alliance between international donors to promote bioethical capacity in developing countries. Among the duties of this proposed bioethical body would be to establish thirty bioethics training centers in developing countries that would each produce twelve trainees a year. ${ }^{167}$ This training project is estimated to cost about $\$ 100,000,000$ in total. ${ }^{168}$ Some international organizations or agencies are already responding to the problems of capacity building in developing countries. For instance, the Forgarty International Center (FIC), at the National Institutes of Health, supports and promotes international collaborative research in priority global health areas with a goal of reducing inequities in global health. ${ }^{169}$ Part of FIC's objective is to "develop human capital and build research capacity in the poorest nations of the world where the need is the greatest." 170 Accordingly, in 2001, FIC announced five awards and three planning grants for the bioethical training of faculty from institutions in developing countries.

Similar support was provided by the Rockefeller Foundation in 1980 through the International Clinical Epidemiology Network (INCLEN), which identified and supported medical schools in a number of developing countries to train faculty in clinical epidemiology. Regionally, the Pan African Bioethics Initiative (PABIN) is a new African regional forum that intends to promote the development of systematic ethical review capacity in African countries. ${ }^{171}$ In this regard, PABIN has already organized regional conferences, including a recent one in Addis Ababa, Ethiopia on 28-30 April 2003. ${ }^{172}$ Similarly, the African Malaria Vaccine Testing Network (AMVTN), now African Malaria Network Trust (AMANET) was established in 1995 to facilitate "the planning, coordination and execution of malaria vaccine trials

166. Assistance in capacity building outside the realm of ethics review was rendered by the Swiss Tropical Institute (STI) between 1997 and 1998. See KFPE, supra note 14, at 24-26. During this time, STI helped the Ghanaian Navrongo Health Research Centre (NHRC) establish a microbiology laboratory to fight the epidemic meningitis afflicting northern Ghana. See id. STI has also provided equipment, and training for Ghanaians through exchange programs. See id. It will be exciting to see such assistance rendered in the area of ethical review.

167. See Singer \& Benatar, supra note 164 , at 747.

168. Id.

169. See Gerald T. Keusch, Welcome to the Forgarty International Center, available at http://www.fic.nih.gov/about/welcome.html (last visited Oct. 4, 2003).

170. Id.

171. See The NuFfield COUNCIL ON BIOETHICS, supra note 6, at 109.

172. See Pan-African Bioethics Initiative, An International Conference on Good Health Research Practices in Africa, available at http://www.fond-merieux.org/enseignement/PABIN \%20meeting\%20in\%202003.pdf (last visited Oct. 4, 2003). 
in Africa."173 AMANET's objectives include developing research and ethics capacity in African countries in connection with its malaria vaccine project. ${ }^{174}$

Another option would be for a research ethics committee in Nigeria to charge fees for the review of research protocols. However, this may undermine the independence of an ethics committee and raise a conflict of interest that is inherently problematic in a commercial or for-profit ethics committee. To ameliorate these concerns, the Nuffield Council on Bioethics suggested that fees should be paid into a central fund or to a local or national government and devoted to financial support of ethics committees. ${ }^{175}$ Absent any visible form of governmental support for ethics committees in Nigeria, it may be prudent to pay more attention to this option and develop ways to mitigate its negative impact on the independence of ethics committees.

\section{CONCLUSION:}

Despite Nigeria's involvement in biomedical research since colonial times, Nigeria does not have any formal framework for regulating research involving human participants. Although the Nuremberg Code and the Declaration of Helsinki apply in Nigeria, it is without the benefit of an implementing and elaborating domestic regulatory instrument. In 1996, Nigeria witnessed a biomedical research scandal that depicted lack of respect for the dignity and welfare of research participants. The research was not preceded by a competent ethics review of the protocol.

The under-regulation of medical research in Nigeria poses an enormous risk of harm to research participants. This risk increases with the globalization of clinical trials. Globalization of biomedical research makes it more lucrative for western biotechnology firms to conduct clinical trials in developing countries that have an abundance of research subjects afflicted with poverty and disease and lacking access to adequate health care. This situation renders citizens of many developing countries vulnerable and liable to research exploitation. Globalization of clinical trials has helped to underscore the inadequacies of current international and domestic research guidelines from developed countries. It has also highlighted the low regulatory visibility in some developing countries such as Nigeria. Thus, there is a need to rethink ethical principles guiding the conduct of biomedical research because their application in cross-cultural settings raises special difficulties.

Some of the provisions of CIOMS that attempt to deal with difficult issues of international biomedical research, such as the requirement for double

173. The African Malaria Vaccine Testing Network, at http://www.amvtn.org (last visited Sept. 17, 2003).

174. See Trust Rules, The Constitution of the African Malarie Vaccine Testing Network, Art. 7 (2002), available at http://www.amvtn.org/Documents/AMANET_Trust_Rules.pdf(last visited Oct. 4, 2003).

175. See The NUFFELD COUNCIL ON BIOETHICS, supra note 6, at 106. 
review of externally sponsored research, are praiseworthy. However, their concrete application may be hampered by many factors, including the lack of bioethical capacity in some developing countries. Thus, this paper suggests that urgent steps be taken in Nigeria to promulgate a biomedical research guideline. Nigeria can draw from the Ugandan experience, whose recent guideline reflects the country's historical, economic, political, and social circumstances. Nigeria also has an urgent need for effective and competent ethics committees. International and regional agencies can help Nigeria develop ethics review capacity through funding, training, and education programs. Ethics review committees in Nigeria may also consider charging fees for protocol review, but this should be developed in a way that obviates harm to their independence. 